\title{
A Rare Cause of Chronic Constipation in The Field of Family Medicine Practice: Dyssynergic Defecation
}

\section{Aile Hekimliği Pratiğinde Nadir Rastlanan Bir Kronik Kabızlık Nedeni: Dissinerjik Defekasyon}

\author{
Onur Öztürk ${ }^{1}$, Tuğba Şenel², Muhammed Okuyucu ${ }^{3}$
}

${ }^{1}$ Samsun Education and Research Hospital, Clinic of Family Medicine, Samsun, Turkey

${ }^{2}$ Department of Internal Medicine, Division of Gastroenterology, Ondokuz Mayıs University Faculty of Medicine, Samsun, Turkey

\section{Öz}

Kabızlık seyrek dışkılama, ağrı, sertlik ve zor dışkı geçişi ile sonuçlanabilen bir bozukluktur ve patogenezi çok faktörlüdür. Otuz iki yaşında kadın hasta çocukluktan beri mevcut olan kabızlık şikâyeti ile aile hekimliği kliniğine başvurmuştur. Etyolojik araştırma yapılan hastada kronik kabızlığın nadir nedenlerinden biri olan dissinerjik defekasyon tespit edilmiştir. Kronik kabızlık; risk faktörlerinin ve etyolojik nedenlerinin göz önünde bulundurularak ayrıntılı bir öyküyle değerlendirilmesi gereken bir durumdur.
\end{abstract}

${ }^{3}$ Department of Internal Medicine, Ondokuz Mayıs University Faculty of Medicine, Samsun, Turkey

Anahtar Kelimeler: Aile hekimliği, kabızlık

\section{Introduction}

Constipation is a disorder that can result in infrequent defecation, pain, stiffness and difficult stool passage. Pathogenesis is multifactorial depending on genetic predisposition, socioeconomic status, low fiber consumption, lack of fluid intake, inactivity, hormonal disorder, side effects of drugs and body anatomy. Appropriate clinical approach is required to evaluate secondary causes such as systemic diseases and drugs (1). After excluding secondary causes of constipation, evaluation should be made for chronic idiopathic constipation, one of the most common gastrointestinal disorders worldwide. Chronic idiopathic constipation is divided into three subtypes as dyssynergic defecation, slow transit constipation, and normal transit constipation, which are problems with rectal defacation (2). In this study, a case having dyssynergic defecation for a long time is discussed.

\section{Presentation of the case}

A 32-year-old female patient was admitted to our family medicine clinic in April 2021 with the complaint of constipation that has been present since childhood. The patient had applied to clinicians several times with this complaint and she was administered pinaverium bromide, lactulose and magnesium hydroxide treatments from time to time. Constipation complaints of the patient, who had benefited from medical treatments for a short time, recurred each time. We learned that

\section{Abstract}

Constipation is a disorder that can result in infrequent defecation, pain, stiffness and difficult stool passage and pathogenesis is multifactorial. A 32-year-old female patient was admitted to family medicine clinic with the complaint of constipation that has been present since childhood. Dyssynergic defecation, which is one of the rare causes of chronic constipation, was detected in the patient whose etiological investigation was carried out. Chronic constipation is a condition that should be evaluated with a detailed medical history, taking into accounts the risk factors and etiological causes. Keywords: Family practice, constipation

the patient, who had no known additional systemic disease and had a normal menstrual cycle, had occasional hemorrhoidal bleeding. In the physical examination of the patient, who did not have any additional findings in the system examination, it was observed that she had mild tenderness in the left lower quadrant upon deep palpation.

In laboratory findings; $\mathrm{Hb}: 8.9 \mathrm{~g} / \mathrm{dL}, \mathrm{MCV}$ : 64.5 fL, RDW: $19.1 \%$, PLT: 367 103/uL, iron: $17.7 \mu \mathrm{g} / \mathrm{dL}$, iron binding capacity: $388 \mu \mathrm{g} / \mathrm{dL}$, iron saturation: $4.5 \%$, ferritin: $3.7 \mathrm{ng} / \mathrm{mL}$, TSH: $3.9 \mu \mathrm{IU} / \mathrm{mL}$, complete urinalysis was found to be normal. Electrocardiograpy was sinus rhythm and abdominal ultrasonography was normal. Upper and lower endoscopies were requested in terms of etiological investigation for the patient with iron deficiency anemia and oral iron preparation treatment was started. In the total colonoscopy evaluation of the patient whose esophagogastrodudenoscopy evaluation was normal, mild melanosis coli and grade 1 internal hemorrhoids were detected. In the first month of iron treatment, iron parameters were found to be normal and Hb: $13.6 \mathrm{~g} / \mathrm{dL}$. Anorectal manometric examination is planned for the etiology of chronic constipation. As a result of the examination; anal sphincter resting pressure is low, pressure increase is sufficient with voluntary contraction of the sphincter, rectoanal inhibitory reflex is normal, there is no sphincter relaxation with straining, and rectal sensitivity is decreased. 
Accordingly, dyssynergic defecation was considered as the cause of chronic constipation in the patient, and biofeedback treatment was recommended for constipation. The patient's constipation complaint was eliminated after the treatment.

\section{Discussion}

Chronic constipation is a condition that should be evaluated with a detailed medical history, taking into accounts the risk factors and etiological causes. Since it is encountered with a prevalence of up to $80 \%$ in the general population (3), it is frequently encountered in routine family medicine practice and therefore it is important to manage it. Constipation is more common over the age of 65 and it is more common in women, as in our patient (4). Our patient applied to clinicians for constipation complaints at various times and used different medical treatments for short-term benefit, but the complaint recurred each time. This revealed the importance of examining the etiological causes in more detail and planning the appropriate investigations in our patient.

The relationship between constipation and the development of colorectal cancer is controversial, and further investigation is required in the presence of alarm symptoms (5). Since our patient had deep anemia as an alarm symptom, endoscopic examination was required. No cancer was found as a result of endoscopic examinations. The cause of the anemia in the patient was thought to be intermittent hemorrhoidal bleeding due to the effect of chronic constipation, and its treatment was planned.

Anorectal manometer is a diagnostic tool that can show rectal reflexes, sensation, compliance, rectosphincter reflex at rest and during defecation, and helps to recognize dyssynergic defecation, especially as in our patient (6,7). Biofeedback therapy is a behavioral approach that can be used to cure inappropriate contraction of the pelvic floor muscles and external anal sphincter during defecation in patients with defecation dysfunction such as dyssynergic defecation $(8,9)$. It has been found that more than $70 \%$ of patients with gastrointestinal disorders were relieved of symptoms with biofeedback therapy (10). Our patient benefited from biofeedback treatment and her constipation complaint was eliminated.

While the causes of chronic constipation, which is difficult to manage in common practice, are being examined, dyssynergic defecation should also be kept in mind, and the patient should be referred for further investigation.

\section{References}

1. Forootan M, Bagheri N, Darvishi M. Chronic constipation: A review of literature. Medicine (Baltimore) 2018;97(20):e10631. doi:10.1097/MD.0000000000010631

2. Black CJ, Ford AC. Chronic idiopathic constipation in adults: epidemiology, pathophysiology, diagnosis and clinical management. Medical Journal of Australia 2018;209:

91. https://doi.org/10.5694/mja18.00241

3. Sanchez MI, Bercik P. Epidemiology and burden of chronic constipation. Can J Gastroenterol 2011;25: 11B-L 15B.

4. Suares NC, Ford AC. Prevalence of, and risk factors for, chronic idiopathic constipation in the community: Systematic review and metaanalysis. Am J Gastroenterol 2011; 106: 15821591; quiz 1, 92.

5. Power AM, Talley NJ, Ford AC. Association between constipation and colorectal cancer: Systematic review and meta-analysis of observational studies. Am

Gastroenterol 2013; 108: 894- 903; quiz 4.

6. Karlbom U, Lundin E, Graf W, et al. Anorectal physiology in relation to clinical subgroups of patients with severe constipation. Colorectal Dis 2004;6:343-9.

7. Rao SS, Meduri K. What is necessary to Diagnose Constipation? Best Pract Res Clin Gastroenterol 2011;25:127-40.

8. Rao SS, Seaton K, Miller M, et al. Randomized controlled trial of biofeedback, sham feedback, and standard therapy for dyssynergic defecation. Clin Gastroenterol Hepatol 2007; 5:331.

9. Heymen S, Scarlett Y, Jones $\mathrm{K}$, et al. Randomized, controlled trial shows biofeedback to be superior to alternative treatments for patients with pelvic floor dyssynergia-type constipation. Dis Colon Rectum 2007; 50:428.

10. American Gastroenterological Association Medical Position Statement on Constipation. Gastroenterology 2013; 144:211-7. 